\title{
COMMENTS
}

\section{The Case for Reviewing Debt/Equity Determinations for Abuse of Discretion}

\author{
Nathan R. Christensen $\dagger$
}

\section{INTRODUCTION}

For at least thirty-eight years, the circuit courts of appeals have been split over the proper standard of review for a trial court's distinction of debt from equity. ${ }^{1}$ Whether a financial disbursement counts as debt or equity is material to the tax treatment it receives. Underlying this split are two central disagreements. One is academic-whether the debt/equity distinction is ultimately a legal or factual determination. The other is practical-whether deferential or independent review will strike the right balance between decisionmaking accuracy and costs. Courts commonly consider three options for standard of review: clearly erroneous, abuse of discretion, and de novo. But on this issue, the circuits are split four ways, with different circuits advocating for the three principal standards as well as a hybrid utilizing both clearly erroneous and de novo review.

The inquiry is complex and dynamic, and clear resolution is needed. ${ }^{2}$ Courts of appeals have been resolving debt/equity cases for over fifty years. But the dust has not yet settled-just last year the Third Circuit formally adopted its position, joining the majority of circuits in classifying the question as factual and the review as for

$\dagger$ BA 2001, Stanford University; JD Candidate 2008, The University of Chicago.

1 Compare Berkowitz v United States, 411 F2d 818, 821 (5th Cir 1969) ("It is not the jury's function to determine whether the undisputed operative facts add up to debt or equity.") with O. H. Kruse Grain v Commissioner, 279 F2d 123, 125 (9th Cir 1960) ("[W] intended to be a bona fide indebtedness or a contribution to capital ... would seem to pose to us merely [a] factual issue.").

2 In other contexts, courts and commentators have noted that the standard of review plays a role in determining the outcome of appellate decisions. See Eugene Volokh and Brett McDonnell, Freedom of Speech and Independent Judgment Review in Copyright Cases, 107 Yale L J 2431, 2441 (1998) (stating that "[c]ourts certainly say that standards of review matter, and it seems that standards of review must sometimes make a difference," and citing examples in which courts have emphasized the importance of standards of review). Based on a survey of debt/equity cases, there is no reason not to believe that the standard of review is not also important in this context as well. See Appendix Table 1: Rate of Reversal by Standard of Review. 
clear error. ${ }^{3}$ Part of the reason this issue remains unresolved is that it straddles the nebulous border between questions of law and questions of fact, territory the Supreme Court has described as "vexing" and "difficult." Courts have not only had trouble identifying and adhering to their own precedent, ${ }^{6}$ but, in addition, no court of appeals has accurately captured the current positions of its sister courts.' Commentators have steered clear entirely.

Because the courts addressing this question have proposed the three principal standards of review, this Comment does not put forward a new solution. Instead, this Comment seeks to clarify the issue by (1) providing an original synthesis of the courts' of appeals diverse positions, (2) creating a framework for determining an optimal standard of review, and (3) applying this framework to settle the circuit split. In short, this Comment breaks new ground by defining the debate and providing a robust approach for arriving at the proper standard of review.

To accomplish these objectives, this Comment proceeds in four parts. Part I examines the relevant background. Part II details the current state of the circuit split. Part III explains why this issue is appropriate for resolution and argues, based on factors drawn from Supreme Court precedent, that deferential review for abuse of discretion is the proper standard to adopt. Part IV provides a brief conclusion.

\section{BACKGROUND}

Whether a transfer constitutes debt or equity is a frequently litigated issue. When courts of appeals encounter debt/equity determinations, judges often signal their familiarity with the issue as if acknowledging an old acquaintance-or, perhaps more accurately, an annoy-

3 See In re SubMicron Systems Corp, 432 F3d 448, 457 (3d Cir 2006) (acknowledging that "[d]irect precedent on this issue is lacking" and concluding "we agree with our Sixth and Ninth Circuit colleagues that this is a question of fact").

4 See Pullman-Standard v Swint, 456 US 273, 288 (1982).

5 See Cooter \& Gell v Hartmarx Corp, 496 US 384, 401 (1990).

6 In Piggy Bank Stations v Commissioner, the Fifth Circuit states that "the question whether payments or disbursements by a taxpayer are to be treated as debts for tax purposes is an issue of fact." 755 F2d 450, 452 (5th Cir 1985). The court mistakes its own precedent in two ways. First, this statement relies on earlier Fifth Circuit precedent addressing the standard of review for distinguishing business debt from nonbusiness debt, not debt from equity. See id, citing Estate of Mann $v$ United States, 731 F2d 267, 273 n 8 (5th Cir 1984) ("Whether an asserted bad debt is a business or non-business debt ... is a question of fact."). Second, this statement contradicts consistent Fifth Circuit precedent holding that debt/equity determinations should be reviewed de novo. See, for example, Estate of Mixon v United States, 464 F2d 394, 403-04 (5th Cir 1972).

7 See, for example, In re SubMicron, 432 F3d at 448 (asserting that only the Fifth, Sixth, Ninth, and Eleventh Circuits have taken positions on the proper standard of review, and thereby ignoring the positions taken by the First, Second, Fourth, Seventh, Tenth, and D.C. Circuits). 
ing neighbor. ${ }^{8}$ There are at least three explanations for why this issue is no stranger to the courts. The first is that a debt/equity distinction is material to many parts of the tax code, including income tax deductions ${ }^{9}$ and bad debt deductions. ${ }^{10}$ The second is that the debt/equity distinction arises in such diverse and nuanced factual scenarios that courts cannot easily develop broad rules to anticipate every possible contextual permutation. The third is that the debt/equity distinction often bears significant financial consequences for the parties involved. In sum, taxpayers must frequently make debt/equity classifications, are uncertain of how the law will judge their classifications given their unique circumstances, and have enough at stake to make litigation worthwhile.

This section provides background information necessary to navigate the labyrinth ahead. The first subsection reviews the tests that have been adopted by different circuits to resolve the underlying debt/equity distinction. The second subsection provides background on the legal contexts in which debt/equity distinctions surface. The third subsection discusses the procedural posture of these cases, including an overview of the Tax Court. The fourth subsection reviews the relevant standards of review.

\section{A. The Underlying Test: Distinguishing Debt from Equity}

Two key terms lie at the center of the underlying issue: debt and equity. As a starting point, both debt and equity are methods for financing an enterprise. Under a debt arrangement, financing is loaned

8 See, for example, In re Lane, 742 F2d 1311, 1313 (11th Cir 1984) (noting at the start of the discussion that "[ $\mathrm{t}]$ he issue of whether advances made by a shareholder to a corporation constitute debt or equity has been one faced by the courts many times"); $A$. R. Lantz Co v United States, 424 F2d 1330, 1331 (9th Cir 1970) (beginning the opinion by stating, "[t]his action deals with the oft-litigated tax issue of whether certain advances made to a corporation created debt, or constituted capital contributions"); Fin Hay Realty Co v United States, 398 F2d 694, 694-95 (3d Cir 1968) (beginning the opinion by stating, "[w]e are presented in this case with the recurrent problem whether funds paid ... were additional contributions to capital or loans").

9 See 26 USC $\S 163$ (a) (2000) ("There shall be allowed as a deduction all interest paid or accrued within the taxable year on indebtedness."). See also Indmar Products Co, Inc v Commissioner, 444 F3d 771, 776 (6th Cir 2006) ("Under 26 U.S.C. \$ 163(a), a taxpayer may take a tax deduction for all interest paid or accrued ... on indebtedness. There is no similar deduction for dividends paid on equity investments.") (quotation marks omitted).

10 See 26 USC \& 166(a)(1) (2000) ("There shall be allowed as a deduction any debt which becomes worthless within the taxable year."). See also Roth Steel Tube Co v Commissioner, 800 F2d 625, 629 (6th Cir 1986) ("The right to a deduction is limited to genuine debt, and capital contributions are not considered debt for the purposes of section 166(a)(1)."). "Bad debt" is defined as "[a] debt that is uncollectible and that may be deductible for tax purposes." Black's Law Dictionary 432 (West 8th ed 2004). 
with the expectation of a regular and settled return." An equity relationship, on the other hand, involves the exchange of financing for ownership, with rights to the financial success of the enterprise. ${ }^{12}$ On the surface, the distinction seems clear.

But no judge has said of debt or equity, "I know it when I see it."," This is because the line between these concepts is often blurred by the imprecise and convoluted financial arrangements that firms adopt in practice. ${ }^{14}$ Thus it may be that debt and equity are best represented along a continuum, in which the ends are easily identifiable but the middle ground is comprised of unfamiliar hybrids featuring elements of both debt and equity.

For cases residing within this middle ground, courts must still determine whether a transaction more closely resembles a debt or equity arrangement. Initially, Congress authorized the Treasury to draft regulations for distinguishing debt from equity. ${ }^{16}$ As a start, Congress provided five factors, which may be included in the regulations: (1) a promise to repay, (2) subordination to indebtedness, (3) the debtequity ratio, (4) convertibility into stock, and (5) the relationship between holdings of stock and holdings of the interest in question." In 1980 , the Treasury issued its regulations. But less than three years later, the regulations were withdrawn and the endeavor abandoned. ${ }^{18}$

To fill the void courts of appeals have created lengthy lists of criteria to distinguish debt from equity. The number of factors considered varies between the circuits. Courts on each side have emphasized that the factors are advisory and of unequal weight, and that no factor

11 "Debt" has been defined as "[1]iability on a claim; a specific sum of money due by agreement or otherwise." Black's Law Dictionary at 432 (cited in note 10).

12 "Equity" has been defined as "[a]n ownership interest in property." Id at 579.

13 Jacobellis v Ohio, 378 US 184, 197 (1964) (Stewart concurring) (discussing the nature of pornography).

14 See Kraft Foods Co v Commissioner, 232 F2d 118, 123 (2d Cir 1956) ("The vast majority of these cases have involved 'hybrid securities' - instruments which had some of the characteristics of a conventional debt issue and some of the characteristics of a conventional equity issue.").

15 One commentator notes: "The case law first approaches the issue by describing a spectrum. At one end is equity, a risk investment with potential to share in corporate profits. At the other end is debt, evidenced by the corporation's unconditional promise to pay back the contributed funds, with market rate interest, at a fixed maturity date." Stephen A. Lind et al, Fundamentals of Corporate Taxation 132 (Foundation 6th ed 2005).

16 Internal Revenue Code, 26 USC $\$ 385$ (a) (2000) ("The Secretary [of the Treasury] is authorized to prescribe such regulations as may be necessary or appropriate to determine whether an interest in a corporation is to be treated for purposes of this title as stock or indebtedness").

1726 USC $\$ 385$ (b) (2000).

18 See Lind, Fundamentals of Corporate Taxation at 143-44 (cited in note 15). Lind suggests that " $[t]$ he regulations were withdrawn because lobbyists convinced the Treasury that they would have a negative impact on particular industries and on small businesses generally." Id at 145. 
is entirely dispositive. ${ }^{19}$ Table 1 illustrates the broad pool of criteria courts consider.

TABLE $1^{20}$

Factors considered in debt/equity determinations

(1) Names given to the financial instruments

Circuits considering ${ }^{21}$

(2) Fixed maturity date

$5,6,9,11$

(3) Source of payments

$1,3,5,6,9,10,11$

$3,5,6,9,11$

(4) Right or attempt to enforce payment

(5) Increased participation in management as a result

$1,5,9,10,11$

$3,5,9,11$

(6) Status of the contribution in relation to other corporate creditors

$3,5,6,9,11$

(7) Intent (subjective) of the parties

(8) Capitalization ('thin' or adequate)

$1,3,5,7,9,10,11$

$3,5,6,9,11$

(9) Identity of interest between creditor and stockholder

(10) Ability of the corporation to obtain loans from outside lending institutions

(11) Extent to which the advance was used to acquire capital assets

$3,5,6,9,11$

$3,5,6,9,11$

$5,6,11$

Failure of the debtor to repay on the due date or to seek a postponement

$1,5,11$

Risk involved

(14) Formal indicia of the arrangement

$1,3,7,10$

(15) Voting power or control of the instrument holder

$1,3,6$

(16) Fixed rate of interest

(17) Contingency on the obligation to repay

(18) Provision for redemption by the corporation 3

(19) Provision for redemption at the option of the holder 3

(20) Timing of the advance with reference to the organization of the corporation 3

(21) Security for advances $\quad 6$

(22) Sinking fund to provide repayments 6

(23) Corporate earnings and dividend history $\quad 1,7,10$

(24) Use of customary loan documentation 1

19 See, for example, Mills v IRS, 840 F2d 229, 235 (4th Cir 1988) ("No single factor or set of factors is controlling."); Estate of Mixon v United States, 464 F2d 394, 402 (5th Cir 1972) (observing that "factors are not of equal significance and that no one factor is controlling").

20 Data were gathered from the following sources: Ellinger v United States, 470 F3d 1325, 1333-34 (11th Cir 2006); Crowley v Commissioner, 962 F2d 1077, 1079 (1st Cir 1992); Roth Steel, 800 F2d at 630; Busch v Commissioner, 728 F2d 945, 948 (7th Cir 1984); Hardman v United States, 827 F2d 1409, 1411-12 (9th Cir 1987); Texas Farm Bureau v United States, 725 F2d 307, 311 (5th Cir 1984); Williams v Commissioner, 627 F2d 1032, 1035 (10th Cir 1980); Fin Hay Realty, 398 F2d at 696.

21 The Second, Fourth, and D.C. Circuits have been excluded because they have not yet proposed a list of factors. 
(25) Treatment accorded disbursements in corporate records

(26) Restrictions on disbursements

(27) Magnitude of disbursements

(28) Repayment history

Indmar $v$ Commissioner ${ }^{22}$ is one of many cases that illustrates both the complicated nature of financial transactions, as well as how courts use the criteria above to separate debt from equity. Indmar is the self-proclaimed "world's largest privately held manufacturer of gasoline powered inboard marine engines." ${ }^{, 23}$ The company notes on its website that it is "still family owned and operated," and it is these family ties that created tax trouble for Indmar in 2005. Indmar's stockholders, now limited to co-founder Richard Rowe, Sr. and his family, began advancing funds to Indmar in the 1970s for a set rate of return.' Though the advances were not initially documented, in 1993, Indmar and the stockholders executed promissory notes and then lines of credit for the outstanding balances Indmar still owed. ${ }^{26}$ However, no maturity date or monthly payment schedule was ever specified. Repayment was made on stockholder demand, such as when the stockholders needed funds for boat repairs or a new home. ${ }^{27}$ From 1998 through 2000, Indmar deducted these payments from its taxable income.

This fact pattern represents a blend of debt and equity characteristics. To disentangle them, the Sixth Circuit analyzed several of the factors listed above. The court began by focusing on evidence regarding the interest rate and interest payments. It found that though the rate exceeded the prime interest lending rate, it was not unreasonable and therefore supported a debt classification. ${ }^{28}$ The court next focused on the documentation of the transactions. The court noted that while initially no written instruments were issued, eventually formal notes were executed, again suggesting a debt arrangement. ${ }^{29}$ The court also examined the source of repayments. ${ }^{30}$ Here the court was presented with contradictory evidence. The primary stockholder testified that he

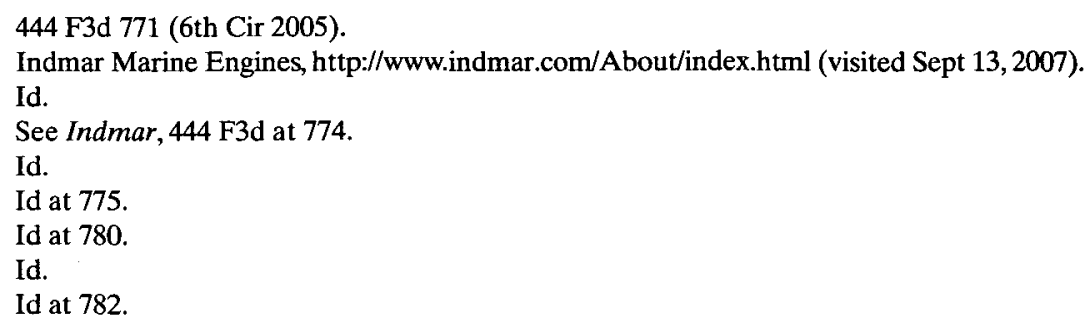


believed that repayment would be made from the company's profits, which is characteristic of an equity relationship, while repayment was in practice often made by taking on additional debt. The Sixth Circuit found that on balance the source of these repayments supported a debt classification. The court also examined several other criteria from the table above in similar fashion. The court concluded that "eight of the eleven ... factors favor debt," and that "the trial evidence, when reviewed as a whole, conclusively shows that the Rowes' advances to Indmar were bona fide loans."

\section{B. Legal Treatment of Debt versus Equity}

The importance of distinguishing debt from equity derives from the tax code's treatment of each. Tax law draws a line down the middle of the debt/equity continuum. It "looks at something decidedly gray and tries to determine whether it more closely resembles black or white." ${ }^{32}$ Transactions on the debt side generally receive favorable treatment. Transactions on the equity side do not. Transactions straddling the middle are pushed to one side or the other, and are subject to the disparate consequences that follow. ${ }^{33}$

The divide between debt and equity is codified in $\S 163(\mathrm{a})$ of the Internal Revenue Code. ${ }^{34}$ The Code provides: "There shall be allowed as a deduction all interest paid or accrued within the taxable year on indebtedness." ${ }^{35}$ In contrast, the Code does not permit deduction for dividends paid on equity investments. ${ }^{36}$ The importance of this discrepancy is illustrated by Indmar. By classifying its disbursements as loan payments, the corporation and its stockholders avoided paying a double tax. ${ }^{37}$ In finding that Indmar's payments did not fall under $\S 163(\mathrm{a})$, the Tax Court levied a deficiency of $\$ 123,735$ and penalties

31 Id at 784.

32 Lind, Fundamentals of Corporate Taxation at 133 (cited in note 15). See also Margaret A. Gibson, Comment, The Intractable Debt/Equity Problem: A New Structure for Analyzing Shareholder Advances, $81 \mathrm{NW}$ U L Rev 452, 460 (1987) (noting that tax law "makes no attempt to accommodate the subtleties involved in corporate finance transactions").

33 Note that 26 USC $\& 385$ was amended to allow (though not require) the Treasury to classify an instrument as “in part stock and in part indebtedness." 26 USC $\$ 385$ (a).

3426 USC \& 163(a).

35 Id.

36 See Indmar, 444 F3d at 776.

37 A double tax arises when the government taxes income at two distinct events: (1) when the income is earned by the corporation, and (2) when the income is distributed to shareholders. See Lind, Fundamentals of Corporate Taxation at 3-4 (cited in note 15). Given this tax and incentive structure, it is not surprising that "stockholders of closely held corporations have preferred to begin operations with a small initial stock investment accompanied by a substantial 'loan' of additional funds." Mixon, 464 F2d at 402. 
totaling $\$ 24,747$ against Indmar. ${ }^{38}$ By reversing the Tax Court, the Sixth Circuit excused Indmar from this deficiency.

The debt/equity classification can also affect an individual's tax liability. If an individual makes a loan to a corporation, the repayment of the principal is tax-free to the individual creditor. ${ }^{39}$ However, any amount received exceeding the creditor's cost basis is a taxable capital gain. ${ }^{40}$ Conversely, if as payment the corporation buys back shares from a shareholder, the entire receipt can be taxed as a dividend. ${ }^{41}$

A third example is provided by 26 USC $\$ 166(a)$. The Code allows deductions for wholly or partially worthless debts. ${ }^{42}$ Thus, a taxpayer's ability to deduct investments that have become worthless depends on whether they are characterized as debt or equity.

Corporate and individual taxpayers are mindful of these disparities in tax treatment, and structure their transactions to their advantage. Consequently, the Internal Revenue Service (IRS) has reason to be suspicious of taxpayer classifications, particularly when a taxpayer categorizes a transaction as debt-based. The tax code responds in two ways. First, it binds the transacting parties to their initial classification of an instrument as debt or equity. This prevents parties from manipulating a classification ex post. Second, the tax code enables the IRS to recharacterize the instrument. ${ }^{43}$

\section{Procedural Posture of Debt/Equity Cases}

The dispute in debt/equity cases arises from tax deficiencies imposed by the IRS. Consequently, the cases generally begin with an IRS tax audit and a finding that the taxpayer's income has been misstated. The IRS then levies a tax deficiency on the taxpayer. Taxpayers may pay the deficiency and file for a refund or dispute the finding before paying the deficiency. Taxpayers file their complaints in the Tax Court, a district court, or the Court of Federal Claims. Or, if the taxpayer is

38 Indmar, 444 F3d at 776.

39 See Gibson, Comment, 81 NW U L Rev at 454 (cited in note 32).

40 See id. See also 26 USC $\S 61(a)(12)(2000)$ (characterizing discharge of indebtedness as gross income).

41 See Lind, Fundamentals of Corporate Taxation at 126 (cited in note 15) ("[W]hen a corporation redeems (i.e., buys back) stock from a shareholder ... the entire amount received may be taxed as a dividend if the shareholder or related persons continue to own stock in the corporation.").

4226 USC $\S 166(a)(1)$ ("There shall be allowed as a deduction any debt which becomes worthless within the taxable year."); 26 USC $\S 166(a)(2)$ ("When satisfied that a debt is recoverable only in part, the Secretary may allow such debt, in an amount not in excess of the part charged off within the taxable year, as a deduction.").

4326 USC \& 385(c)(1) (2000) ("The characterization (as of the time of issuance) by the issuer as to whether an interest in a corporation is stock or indebtedness shall be binding on such issuer and on all holders of such interest (but shall not be binding on the Secretary [of the Treasury])."). 
insolvent due to the tax deficiency or other financial burdens, the taxpayer may choose to file his claim in bankruptcy court.

In court, the taxpayer assumes the burden of proving that his original tax return properly characterized the transaction as debt or equity." Placing the burden on the taxpayer makes sense given that the determination is fact-dependent and that the taxpayer has much greater access to the relevant information. To overcome this presumption, the taxpayer can prove that the Commissioner's determination was either incorrect or arbitrary. The trial court will issue its judgment either affirming or reversing the IRS's determination. To dispute this determination, the taxpayer or IRS must file an appeal in the appropriate circuit court of appeals.

Although a taxpayer may file a debt/equity-related complaint in the district court, the Court of Federal Claims, or even bankruptcy court, the primary forum for adjudicating disputes with the IRS is the Tax Court. One explanation for the volume of debt/equity cases the Tax Court receives is that it is the only court in which the taxpayer does not need to pay the deficiency before filing a complaint. ${ }^{45}$ Cutting in the opposite direction is the historical concern that the Tax Court is biased in favor of the government. ${ }^{46}$ Whether such allegations are accurate, the Tax Court continues to resolve a large number of cases. Due to its central role at the trial level, this Comment will briefly review the characteristics of this court.

Though its origins date back to 1924, the modern Tax Court took shape through the Tax Reform Act of 1964. This Act conferred the status of a specialized legislative court on the Tax Court under Article I of the Constitution." The Court is comprised of nineteen presidentially

44 See Indmar, 444 F3d at 771, citing Ekman v Commissioner, 184 F3d 522, 524 (6th Cir 1999) ("[T]he [IRS] Commissioner's determination of a deficiency is entitled to a presumption of correctness.").

45 See David Laro, Panel Discussion: The Evolution of the Tax Court as an Independent Tribunal, 1995 U Ill L Rev 17, 18 ("The ability of a taxpayer to litigate in the Tax Court without a prior payment of tax is the primary reason many taxpayers choose to pursue a tax dispute ... in the Tax Court."). According to Laro, "[o]ver 95 percent of all tax-related litigation is adjudicated in [the Tax Court]." Id.

46 See, for example, James Edward Maule, Instant Replay, Weak Terms, and Disputed Calls: An Empirical Study of Alleged Tax Court Bias, 66 Tenn L Rev 351, 353-64 (1999) (discussing commentators' views on bias and concluding that "the allegations of Tax Court judge bias advanced by various commentators are not only deceptively tempting misrepresentations but also superficially appealing conclusions for which genuine, statistically significant empirical evidence is lacking"); Laro, 1995 U Ill L Rev at 24 (cited in note 45) (discussing the issue of bias and noting that "[t]wo of the more popular [explanations for bias] are that the composition of the Tax Court makes it more sympathetic to the IRS's position, and statistics show that the government generally prevails in the Tax Court").

47 See Laro, 1995 U Ill L Rev at 22 (cited in note 45). 
appointed judges. ${ }^{48}$ A small group of senior judges and special trial judges also hear cases. ${ }^{49}$ Judges serve a term of fifteen years. ${ }^{50}$ The court sits in Washington, D.C., but conducts trials in eighty cities nationwide.

The relationship between the Tax Court and the reviewing courts of appeals has been an evolving one. The Tax Court initially held that when a disagreement between the Tax Court and applicable court of appeals arose, "to avoid confusion [the Tax Court] should follow its own honest beliefs until the Supreme Court decides the point." was the rule even though it meant that such decisions would be met with almost certain reversal upon review. However, in 1970, the Tax Court reversed its precedent, and held that "better judicial administration requires us to follow a court of appeals decision which is squarely in point where appeal from our decision lies to that court of appeals and to that court alone." ${ }^{53}$

The level of deference accorded the Tax Court by the courts of appeals has also been a point of contention. In Dobson v Commissioner, ${ }^{\text {s4 }}$ the Supreme Court restricted the level of scrutiny courts of appeals could apply to Tax Courts decisions: "[W]hen the court cannot separate the elements of a decision so as to identify a clear-cut mistake of law, the decision of the Tax Court must stand." "S However, in 1948 Congress revoked this rule. ${ }^{56}$ By statute the federal courts of appeals "have exclusive jurisdiction to review the decisions of the Tax Court ... in the same manner and to the same extent as decisions of the district courts in civil actions tried without a jury." ${ }^{\text {s7 }}$ As illustrated by the current circuit split, courts of appeals have disagreed about how best to exercise this discretion.

D. Standards of Review

When courts of appeals assess lower courts' debt/equity decisions, they have a relatively limited set of standards of review to apply. "For

4826 USC \& 7443(a)-(b) (2000).

49 See United States Tax Court: About the Court, http://www.ustaxcourt.gov/about.htm (visited Sept 13, 2007).

5026 USC $\$ 7443(\mathrm{e})$.

51 Maule, 66 Tenn L Rev at 364 (cited in note 46).

52 Lawrence v Commissioner, 27 TC 713, 716-17 (1957), revd, 258 F2d 562 (9th Cir 1958).

53 Golsen v Commissioner, 54 TC 742, 757 (1970).

54320 US 489 (1943).

55 Id at 502 .

56 See Steve R. Johnson, The Phoenix and the Perils of the Second Best: Why Heightened Appellate Deference to Tax Court Decisions Is Undesirable, 77 Or L Rev 235, 236 (1998) ("It was widely thought that Congress had legislatively reversed Dobson in 1948 when it enacted the predecessor of current I.R.C. section 7482.").

5726 USC $\$ 7482(a)(1)(2000)$. 
purposes of standard of review, decisions by judges are traditionally divided into three categories, denominated questions of law (reviewable de novo), questions of fact (reviewable for clear error), and matters of discretion (reviewable for 'abuse of discretion')., ${ }^{\text {'s }}$ Each of these standards has been applied to debt/equity determinations. A brief overview of each follows.

Determinations of fact are reversed only if found to be clearly erroneous. This rule was codified in the Federal Rules of Civil Procedure. ${ }^{59}$ A decision is clearly erroneous "when although there is evidence to support [the decision], the reviewing court on the entire evidence is left with the definite and firm conviction that a mistake has been committed."

Legal determinations receive considerably less deference. Appellate courts are free to review trial courts' conclusions of law de novo, which means that no deference is due the trial court's determination. ${ }^{6}$ This means that while a court looking for clear error will "uphold any district court determination that falls within a broad range of permissible conclusions," ${ }^{, 62}$ a court applying de novo review will reverse if the trial court has not made the best possible decision.

Third, discretionary rulings, and occasionally questions of mixed fact and law, are reviewed for abuse of discretion. An appellate court should reverse under an abuse of discretion standard only when the appellate court believes that the trial court "based its ruling on an erroneous view of the law or on a clearly erroneous assessment of the evidence." Importantly, "[w]hen an appellate court reviews a district court's factual findings, the abuse of discretion and clearly erroneous standards are indistinguishable."

In closing, it is worth noting that the standard of review does not influence the outcome in every case. The standard of review is only outcome-determinative when the court of appeals disagrees with the district court's determination, but does not disagree strongly enough to find it clearly erroneous or an abuse of discretion. ${ }^{65}$ In these cases a judgment is affirmed under clearly erroneous or abuse of discretion, but not under de novo review. In other words, the standard of review is determinative only when there is mild disagreement between the

Pierce v Underwood, 487 US 552, 558 (1988).

See FRCP 52(a) ("Findings of fact ... shall not be set aside unless clearly erroneous.").

United States v US Gypsum Co, 333 US 364, 395 (1948).

See Buford v United States, 532 US 59, 64 (2001).

Cooter \& Gell v Hartmarx Corp, 496 US 384, 400 (1990).

Id at 405 .

Id at 401.

For one articulation of this principle, see Salve Regina College v Russell, 499 US 225, 238 (1991). 
appellate court and trial court. The fact that the standard of review affects the outcome in this limited subset of cases does not diminish the importance of getting it right. Understanding the extent to which the standard of review plays a role is an important consideration in determining how much in error minimization or other benefits society receives for its investment in greater scrutiny.

\section{THE CIRCUIT SPLIT}

Neither commentators nor courts have accurately and thoroughly captured the positions of the courts of appeals on this issue. This Part collects the courts' positions and synthesizes the primary arguments they advance in support.

\section{A. Clearly Erroneous Review}

The First, ${ }^{66}$ Second, ${ }^{67}$ Third, ${ }^{68}$ Fourth, ${ }^{69}$ Sixth, ${ }^{70}$ Seventh, ${ }^{11}$ and Ninth ${ }^{72}$ Circuits classify a trial court's determination of debt or equity as a factual finding, giving the trial court's assessment significant deference and reversing only upon a finding of clear error. These courts assert that debt/equity distinctions turn on the transacting parties' intent. Under this view, the goal of the inquiry is to determine "whether the objective facts establish an intention to create an unconditional obligation to repay the advances." look to objective facts to determine intent, it is the taxpayer's actual intent or actual motive with which we are concerned." ${ }^{74}$ Intent, in short, is dispositive.

Once the issue is boiled down to intent, the clearly erroneous standard gains traction under Duberstein v Commissioner. ${ }^{75}$ In Duberstein, the Supreme Court settled the standard of review for lower courts' distinctions of taxable receipts from tax-exempt gifts. Duber-

66 See generally Crowley v Commissioner, 962 F2d 1077 (1st Cir 1992).

67 See Tollefsen $v$ Commissioner, 431 F2d 511, 513 (2d Cir 1970).

68 See In re SubMicron Corp, 432 F3d 448, 457 (3d Cir 2006).

69 See generally Road Materials v Commissioner, 407 F2d 1121 (4th Cir 1969).

70 See generally Berthold $v$ Commissioner, 404 F2d 119 (6th Cir 1968).

71 See generally Busch v Commissioner, 728 F2d 945 (7th Cir 1984). In Busch, the court overruled prior precedent, which held that the debt/equity determination was a mixed question of law and fact. For the prior precedent, see Spheeris v Commissioner, 284 F2d 928, 931 (7th Cir 1960).

72 See Earle v W. J. Jones \& Son, Inc, 200 F2d 846, 847 (9th Cir 1952).

73 Indmar, 444 F3d at 776, citing Roth Steel Tube Co v Commissioner, 800 F2d 625, 629-30 (6th Cir 1986). See also Crowley, 962 F2d at 1079 ("A shareholder distribution is a loan, rather than a constructive dividend, if at the time of its disbursement the parties intended that it be repaid."); Bauer v Commissioner, 748 F2d 1365, 1367 (9th Cir 1984) (stating that distinguishing debt from equity focuses on determining the parties' intent).

74 Busch, 728 F2d at 949.

75363 US 278 (1960). 
stein involved two separate claims for gifts. One plaintiff received a Cadillac as a thank you for supplying promising sales leads, ${ }^{76}$ the other plaintiff received cash at retirement allegedly in appreciation for good work. ${ }^{n}$ Neither plaintiff reported his receipt, and the IRS imposed tax deficiencies in each case.

The Court focused the inquiry on the transferors' intent. Specifically, the Court held that the proper criterion for characterizing a transfer as a gift or taxable income "is one that inquiries [sic] what the basic reason for [the transferor's] conduct was in fact." ${ }^{78}$ The Court also noted:

The nontechnical nature of the statutory standard, the close relationship of it to the data of practical human experience, and the multiplicity of relevant factual elements, with their various combinations, creating the necessity of ascribing the proper force to each, confirm us in our conclusion that primary weight in this area must be given to the conclusions of the trier of fact. ${ }^{79}$

Thus, the Court determined that the inquiry into intent is a factual matter left primarily to the trial court. The Court concluded that though some legal symmetry and tidiness may be sacrificed, "the question here remains basically one of fact, for determination on a caseby-case basis." 80

Courts within the majority cite parallels between Duberstein and the debt/equity context. ${ }^{81}$ These courts assert that debt/equity transactions are sufficiently analogous to gifts to hold that, like in Duberstein, the factual question of intent is the end, not means, of the inquiry. ${ }^{82} \mathrm{~A}$ Sixth Circuit judge articulated Duberstein's relevance as follows:

While I recognize that Duberstein dealt with tax concepts of "gift" versus "compensation" and that in ... this case we deal with tax concepts of "loans" versus "dividends" or "equity," it seems to me that the reasoning of ... Duberstein affords us no meaningful distinction on factual grounds as far as standard of review is concerned. ${ }^{83}$

76 Id at $280-81$.

77 Id at $281-83$.

78 Id at 286.

79 Id at 289

80 Id at 290.

81 See Busch, 728 F2d at 949 (citing cases in which courts of appeals have relied on Duberstein for the conclusion that the inquiry into intent is a factual matter).

82 See, for example, Estate of Taschler $v$ United States, 440 F2d 72, 75 (3d Cir 1971); Estate of Chism v Commissioner, 322 F2d 956, 960 (9th Cir 1963).

83 Austin Village, Inc $v$ United States, 432 F2d 741, 746 (6th Cir 1970) (Edwards concurring). 
In addition to finding Duberstein persuasive precedent, courts in the majority argue that deference is warranted by the importance of witness testimony in resolving debt/equity disputes. The Seventh Circuit emphasized that the debt/equity question generally involves "the taxpayer testif[ying] as to his intent to repay.", This and other testimony elevates the importance of assessing each witness's credibility. "Findings as to the design, motive and intent with which men act depend peculiarly upon the credit given to witnesses by those who see and hear them." ${ }^{, 5}$ The courts assert that a clearly erroneous standard is therefore particularly appropriate since lower courts will be in a better position to make credibility determinations. ${ }^{86}$

However, even within these courts this position has not been without controversy. In Austin Village, Inc v United States, ${ }^{87}$ the Sixth Circuit wavered: "Although this court has consistently treated the issue of whether advances to a corporation constitute debt or equity as a question of fact ... on conceptual analysis the better view may be that this issue is a question of law." ${ }^{88}$ Two weeks later, in Livernois Trust $v$ Commissioner, ${ }^{99}$ Judge McCree, the author of the majority opinion in Austin Village, concurred in the judgment but disagreed with the court's application of a clearly erroneous standard of review. ${ }^{90}$ The judge distinguished the context from Duberstein on the grounds that in debt/equity "the objective indicia of the transaction are determinative of its legal consequences." ${ }^{\text {"1 }}$ Thus, while in the gift context intent defines the status, in debt/equity, parties may subjectively believe that they are transacting in debt, but the "economic reality" may be just the opposite. Findings of objective indicia are factual inquiries, "[b]ut the determination of the legal effect of the existence of these indicia is ... a question of law."

The Ninth Circuit has also showed signs of doubt. In Taft v Commissioner, ${ }^{93}$ the court found the Tax Court's decision to be clearly erroneous. But the authoring judge confessed that "[t]o this writer the question appears to be [a] mixed question of law and fact."

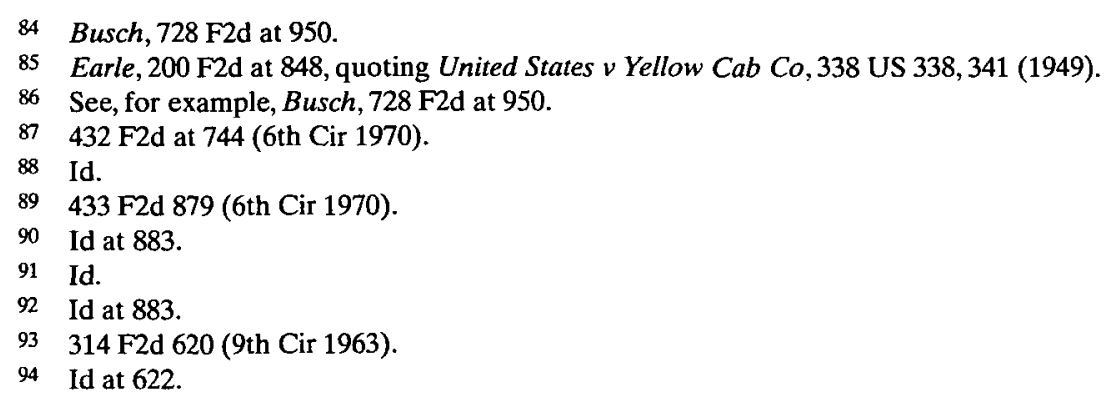


B. De Novo Review

The Fifth ${ }^{95}$ and Eleventh ${ }^{96}$ Circuits hold that the debt/equity question is a legal determination. Therefore, the proper standard of review is de novo. These courts advance two primary arguments.

First, the courts argue that intent is not necessarily dispositive. "The approach ... has been to consider all the factors and weigh the evidence favoring characterization of the advance as debt or equity, while realizing that the various factors are not of equal significance and that no one factor is controlling." In Berkowitz v United States, the Fifth Circuit specifically rejected the appellants' argument that intent was the controlling factor. Instead, the court noted that the parties had objectively manifested their intent, so subjective intent was not determinative."

A second but related line of argument is that the debt/equity determination encompasses two distinct stages of inquiry. The first involves reviewing the criteria and establishing the basic facts relevant to classification. These determinations are given significant deference. ${ }^{100}$ The second requires a legal judgment about "whether the undisputed operative facts add up to debt or equity." phase, "[t]he object of the inquiry is not to count factors, but to evaluate them." ${ }^{102}$ Therefore, while subsidiary findings are given deference, "the ultimate characterization of the transactions as debt or equity receives no such protection."

On this side, too, there is some inconsistency. In Plantation Patterns, Inc $v$ Commissioner, ${ }^{104}$ the Fifth Circuit cited Berkowitz and Mixon for illustrative examples of the Circuit's approach to debt/equity cases. ${ }^{105}$ But the court's only characterization as to standard of review was its curious statement that "[n]one of the Tax Court's Findings and Conclusions based upon stipulated facts are shown to be "clearly erroneous." "106 Similarly, in Rowan $v$ United

95 See generally Berkowitz v United States, 411 F2d 818 (5th Cir 1969).

96 See In re Lane, 742 F2d 1311, 1315 (11th Cir 1984).

97 Estate of Mixon v United States, 464 F2d 394, 402 (5th Cir 1972).

98411 F2d 818 (5th Cir 1969).

99 Id at 821 ("Nor are we persuaded by appellants' arguments that the case [at bar] is one in which there is a controlling significance to the intent of the parties.").

100 See Slappey Drive Industrial Park v United States, 561 F2d 572, 582 (5th Cir 1977) ("We must uphold the district court's findings of basic facts unless clearly erroneous.").

101 Berkowitz, $411 \mathrm{~F} 2 \mathrm{~d}$ at 821.

102 Tyler $v$ Tomlinson, 414 F2d 844, 848 (5th Cir 1969).

103 Slappey Drive, $561 \mathrm{~F} 2 \mathrm{~d}$ at 582.

104462 F2d 712 (5th Cir 1972).

105 Id at 719.

106 Id at 724. 
States, ${ }^{107}$ the Fifth Circuit noted that the trial court's "finding that 'the advances by the partnership to the corporation were contributions to the capital of that corporation rather than loans' is without evidence to support it, and is clearly erroneous."

Moreover, it is worth emphasizing that the Eleventh Circuit's position can be traced to its adoption of general Fifth Circuit precedent. ${ }^{109}$ Three years after adopting Fifth Circuit precedent in Bonner $v$ Pritchard, the Eleventh Circuit resolved a debt/equity dispute according to the Fifth Circuit's calculus. On the question of standard of review, the court made no comment other than to quote Slappey and Mixon's assertions that the ultimate question is one of law deserving no deference. ${ }^{110}$ Therefore, though the Eleventh Circuit sits squarely within this camp, its position may have been considered less deliberately than the other circuits.

\section{Contingent Review}

The Tenth Circuit established a position that can be characterized as a middle ground between the clearly erroneous and de novo camps. In essence, the Tenth Circuit holds that the standard of review is contingent upon whether there is any dispute as to the facts of the case. Precedent is limited, so it is worth reviewing the relevant holdings in some detail.

In Dolese v United States," the court affirmed the district court's summary judgment that payments of the business owner's debts were constructive dividends, not loans. The court held that distinguishing debt from equity "is normally a fact issue, to be determined after trial... But when there is no dispute in the evidence, it is a question of law whether the facts add up to debt or dividend."112 Thus, unlike the circuits advocating de novo review, the Tenth Circuit concluded that the debt/equity issue could be a legal question. But unlike the Fifth and Eleventh Circuits, it also suggested the opposite - when the underlying facts are disputed, it is purely a factual question.

The Tenth Circuit addressed this issue again in Williams $v$ Commissioner. ${ }^{113}$ In Williams, the court cited Duberstein and then asserted that, in "[a]pplying this rule, the conclusion of the trial court that the

\footnotetext{
107219 F2d 51 (5th Cir 1955).

108 Id at 56.

109 See generally Bonner v Pritchard, 661 F2d 1206 (11th Cir 1981).

110 In re Lane, $742 \mathrm{~F} 2 \mathrm{~d}$ at 1315.

111605 F2d 1146 (10th Cir 1979).

112 Id at 1153.

113627 F2d 1032 (10th Cir 1980) ("Our consideration of all the mentioned factors presents the problem of the scope of appellate review.").
} 
taxpayers did not intend to repay [was] a reasonable inference supported by substantial evidence and not clearly erroneous." ${ }^{14}$ But the court continued: "If, because the transactions are undisputed, we have a question of law ... we must consider whether the expressed intent to repay and circumstances of repayment outweigh the facts pertaining to the withdrawals." record presents a fact question, a law question, or a mixed question of law and fact, we agree with the Tax Court that the withdrawals were constructive dividends and not debts."

As illustrated by these two holdings, the Tenth Circuit's approach is difficult to pinpoint. The court apparently suggests that the nature of the debt/equity question, and thus the deference owed, depends on whether subsidiary factual findings are required. This may be more a strategic choice about allocating decisionmaking rather than a legal determination about the underlying debt/equity inquiry. The court may be reasoning that when facts are in dispute, the trial court will be best equipped to make the ultimate determination based on its superior access to the evidence. But when facts are not in dispute, the trial court's advantage disappears and the appellate court should play a more active role. Either way, the court strives to strike a balance between the de novo and clearly erroneous standards, but in doing so stumbles over its own lack of clarity.

\section{Abuse of Discretion Review}

The D.C. Circuit adopted a fourth alternative. In Cerand \& Co v Commissioner, ${ }^{117}$ the court discussed the circuit split over the proper standard of review and concluded that an abuse of discretion standard was appropriate. ${ }^{118}$ In eschewing the positions of the other circuits, the D.C. Circuit relied solely on the Supreme Court's decision in Cooter \& Gell $v$ Hartmax Corp. ${ }^{119}$ In Cooter \& Gell, the Court concluded that abuse of discretion is the proper standard of review for a district court's imposition of Rule 11 sanctions. ${ }^{120}$

In drawing on Cooter \& Gell, the D.C. Circuit found parallels between the Rule 11 and debt/equity contexts. Most importantly, both Rule 11 and debt/equity determinations "require[] the court 'to marshal the pertinent facts and apply [a] fact-dependent legal stan-

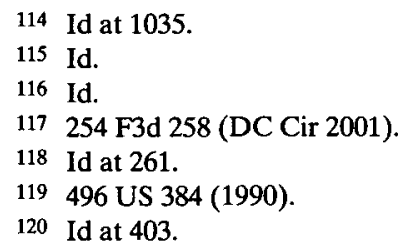


dard." ${ }^{121}$ The D.C. Circuit also found two arguments in favor of abuse of discretion as persuasive in debt/equity cases as they were in the Rule 11 context. First, debt/equity questions, like Rule 11 questions, involve "fact-bound resolutions [that] cannot be made uniform through appellate review, de novo or otherwise." ${ }^{, 22}$ Second, especially in factintensive inquiries, "the district court is better positioned to make the relevant factual determinations." ${ }^{123}$ The D.C. Circuit provided little reasoning or analysis beyond citing Cooter \& Gell. But on this basis it struck new ground and adopted the abuse of discretion standard.

Though it has only been applied once, this standard features some important differences from the others. Unlike a de novo standard, abuse of discretion gives significant deference to the trial court's ultimate determination. But unlike the clearly erroneous standard, it recognizes that the question is not simply one of fact, and thereby imposes some review, albeit deferential, of the trial court's judgment. Finally, it differs from the Tenth Circuit's contingent review approach by providing a single standard applied uniformly regardless of whether the facts are in dispute.

\section{TOWARDS A UNIFORM STANDARD}

Appellate review consumes the resources of, among others, parties, attorneys, and courts. The standard of review dictates the amount of resources that society chooses to invest in reviewing a specific legal problem. To determine the right investment for review of debt/equity determinations, this Comment analyzes the contribution appellate review can make in this context. ${ }^{124}$ This Comment proceeds in four discrete steps. First, Part III.A addresses the viability of establishing a uniform standard of review while the underlying test for making debt/equity distinctions remains unsettled. Second, Part III.B targets the optimal level of deference by applying criteria drawn from Supreme Court precedent. Third, Part III.C reviews fairness, forum shopping, and transactional clarity considerations. Last, concluding that a deferential standard of review is appropriate, Part III.D argues that between clearly erroneous and abuse of discretion, the latter is the better choice.

121 Cerand, 254 F3d at 261, quoting Cooter \& Gell, 496 US at 402.

122 Id, quoting Cooter \& Gell, 496 US at 405.

123 Id.

124 See Richard A. Posner, Economic Analysis of Law 600 (Aspen 7th ed 2007) (explaining that the two purposes of appellate courts are to "reduce the costs of legal error" and "to enable uniform rules of law to be created and maintained"). See also Salve Regina College v Russell,499 US 225, 231 (1991) ("Independent appellate review of legal issues best serves the dual goals of doctrinal coherence and economy of judicial administration."). 
A. Settling the Standard of Review Prior to Settling the Underlying Test

As a threshold matter, it is important to determine whether the standard of review can and should be resolved while the underlying debt/equity test remains unsettled. ${ }^{125}$ There are three primary reasons to answer this question in the affirmative. First, precedent suggests that it is not uncommon for the standard of review to be addressed before the underlying rule has been clearly resolved. Second, given the nature of the debt/equity distinction, it may be preferable to leave the underlying test unresolved. Third, the proper standard of review in this context should not depend on the particulars of the underlying test.

First, a settled underlying test is not always a prerequisite for resolving the standard of review. One need look no further than Duberstein for support. There the government requested that the Court "promulgate a new 'test' in this area to serve as a standard." ${ }^{126}$ The Court flatly declined this request. Instead, it found that "the problem is one which ... does not lend itself to any more definitive statement that would produce a talisman for the solution of concrete cases." ${ }^{127}$ The Court continued, "Were we to promulgate this test as a matter of law ... [we] would be painting on a large canvas with indeed a broad brush." ${ }^{122}$ Notably, its refusal to adopt a formal test for gifts did not hold the Court back from deciding the proper standard of review. Therefore, Duberstein suggests that a settled and clear substantive definition is not a prerequisite for settling the standard of review.

Second, it may be preferable to leave the underlying test unsettled. As shown by Table 1, the circuit courts' approaches to the underlying debt/equity distinction overlap considerably. Every circuit balances objective indicia, and several criteria, such as a corporation's capitalization or the presence of a fixed maturity date, are part of the analysis for every circuit. Given this limited consensus, society may be better off not resolving the underlying test further. Like in the gift context, giving courts flexibility to innovate and experiment with new criteria may best enable them to address the significant factual permutations and dynamic nature of financial instruments. As Duberstein indicates, this does not detract from the value of an efficient and uniform standard of review.

Third, the proper standard of review should not depend on the specific criteria included in the underlying debt/equity test. This asser-

\footnotetext{
125 See Part I.A. for a summary of the underlying test.

126363 US at 284.

127 Id at 285.

128 Id at 287
} 
tion involves both an observation and a substantive argument. The observation is that most of the factors courts analyze do not have implications for the proper standard of review. For instance, whether the final determination took account of the presence or absence of a fixed interest rate is irrelevant to the standard of review. This is made plain by the fact that not every factor can be assessed in every case, and the standard of review should remain uniform regardless of the specific evidence available. The substantive argument centers on whether intent should be entirely dispositive. If intent is dispositive, then precedent suggests that the issue is factual and the standard of review is clear error. ${ }^{129}$ It is a close call, but precedent and reason suggest that intent should not be entirely dispositive.

First, there is no clear indication from precedent that intent should be dispositive in this context. Supreme Court cases dealing with issues of intent give conflicting signals for the debt/equity context. In Duberstein, the Court cited a dissenting opinion from Bogardus v Commissioner $^{130}$ for the principle that in determining whether a transfer was a gift "[w]hat controls is the intention with which payment ... has been made." away from the notion that intent is entirely dispositive. First, in the preceding sentence the Court characterized the transferor's intent as "the most critical consideration." ${ }^{132}$ This language implies that there are other, less-critical considerations. Second, the Court noted that the "donor's characterization of his action is not determinative-that there must be an objective inquiry as to whether what is called a gift amounts to it in reality." ${ }^{133}$ The use of the term "reality" distinguishes the inquiry from strictly one of honest subjective intent.

A second case cited for the principle that intent is dispositive is Pullman-Standard $v$ Swint. ${ }^{134}$ In Pullman, the Court determined that the question of discriminatory intent in Title VII cases is a factual one. However, in the Pullman context, the relevant statutory language attached liability directly to intent. ${ }^{135}$ If applied to the debt/equity context, a taxpayer would be liable for a deficiency if he intended his transaction to be equity even if its economic substance was debt. Moreover, the Court explained that "[d]iscriminatory intent here

129 See Pullman-Standard v Swint, 456 US 273, 288 (1982) ("Treating issues of intent as factual matters for the trier of fact is commonplace.").

130302 US 34,45 (1937).

131 Duberstein, 363 US at 286, quoting Bogardus, 302 US at 45 (Brandeis dissenting).

132 Duberstein, 363 US at 286.

133 Id.

134456 US 273 (1982).

135 Id at 286 ("As indicated in the text ... the question of intentional discrimination under $\S 703$ (h) [of Title VII (42 USC 2000e-2(h)) (2000)] is a pure question of fact."). 
means actual motive; it is not a legal presumption to be drawn from a factual showing of something less than actual motive." ${ }^{136}$ However, in debt/equity cases, courts may make a determination when the criteria tested suggest a particular characterization even where the actual motive remains unclear.

Although precedent is unclear, pragmatic considerations point more directly towards using intent as a significant but not controlling factor. First, characterizing the inquiry as one based solely on intent presumes that the taxpayer had a clear intent. But it may be that the taxpayer may have acted without fully considering his expectations. ${ }^{137}$ Further, in the case of a corporate taxpayer, the intent issue may be clouded by multiple decisionmakers. Second, it is conceivable that a taxpayer's intent does not match the proper legal characterization. ${ }^{138} \mathrm{~A}$ taxpayer unaware of the legal rules and financial structures may intend to make a tax-deductible loan but badly misunderstand the divide between debt and equity. Consequently, his transaction may bear the indicia of equity. It is this "economic substance" of the transaction that should be determinative of its tax treatment."

Whether intent is absent, unclear, or misleading, in these cases there is work for the trial court to do beyond making a factual determination as to intent. ${ }^{140}$ The court must determine the relevant pool of criteria, weigh contradictory evidence, and attach relative significance to the various factors. Consequently, it is not surprising that courts focus much more on investigating the specific details of the transaction rather than the character, background, and skill of the transactor. In short, reducing this inquiry solely to intent misrepresents the proc-

136 Id at $289-90$.

137 For example, in one case the taxpayer was asked whether it was his intent to not be repaid if the company became unprofitable. The taxpayer responds, "I had no intentions of not being repaid, sir." When asked why, he continued, "I believe it's me. It's my personality." Indmar, 444 F3d at 781.

138 See, for example, Kraft Foods Co v Commissioner, 232 F2d 118, 123 (2d Cir 1956) ("In such a case we think the problem is not one of ascertaining 'intent,' since the parties have objectively manifested their intent. It is a problem of whether the intent and acts of these parties should be disregarded in characterizing the transaction for federal tax purposes.").

139 See In re Indian Lake Estates, Inc, 448 F2d 574, 578 (5th Cir 1971) (characterizing an investment as equity though "the instruments involved took the form of loan documents; some of these obligations bore interest; all of them had a fixed maturity or payment date; the obligation to repay was geared to gross sales and was not conditioned upon business success ... [and] the parties advancing the financing did not subordinate their claims to common creditors but demanded a superior repayment position").

140 See, for example, Texas Farm Bureau v United States, 725 F2d 307, 314 (5th Cir 1984) ("Primary reliance upon subjective indications of intent is simply not an effective way of resolving that problem. In a land of hard economic facts, we cannot root important decisions in parties' pious declarations of intent."). 
ess of evaluating objective indicia, and making a judgment about the economic substance expressed by those indicia.

For these reasons, examining the standard of review before settling the underlying debt/equity test is not premature. While intent is highly relevant, it does not reflect the full scope of the debt/equity inquiry. Therefore, requiring resolution of the underlying inquiry prior to settling the standard of review is both unnecessary and unwise.

\section{B. Considerations Drawn from Precedent}

While no Supreme Court case is directly on point, several cases resolving circuit splits over the appropriate standard of review are instructive. Though "it is uncommonly difficult to derive from the pattern of appellate review of other questions an analytical framework that will yield the correct answer," of considerations to guide the inquiry. This section reviews six such guideposts drawn from precedent.

1. The nontechnical nature of the inquiry favors deference.

As the Court pointed out in Duberstein, whether the legal standard is highly technical may be relevant to the appropriate standard of review. ${ }^{142}$ If the legal standard is highly technical, accurate classifications are more likely to require specialized knowledge. The inference from Duberstein is that if specialized knowledge is not required, deference is appropriate. Put simply, the more straightforward the inquiry, the greater the accuracy of the trier of fact, and therefore the less appellate review can reduce error costs.

The legal standard applied in debt/equity determinations suggests that the trier of facts should be a relatively accurate decisionmaker on this account. According to Duberstein, a technical standard may exist where either (1) the statutory standard is complex, or (2) the activities and evidence the standard relies upon are unfamiliar to people without specialized knowledge. ${ }^{143}$ Duberstein concluded that the classification of an exchange as a gift or income is within the trier of fact's competence. Debt/equity classifications, like gift classifications, do not fulfill the two criteria listed above. First, the statutory standards for

141 Pierce v Underwood, 487 US 552, 559 (1988).

142 Duberstein, 363 US at 289 (asserting that the "nontechnical nature of the statutory standard" and "the close relationship of it to the data of practical human experience" weighs in favor of deference).

143 See id. 
the tax treatment accorded debt are straightforward. ${ }^{144}$ The standard revolves around a key term, and there is definitional symmetry between the terms in both the gift and debt contexts. In determining whether the term captures the facts at hand, the inquiry is what, if anything, the exchange obligated the receiver to provide. ${ }^{145}$ Second, like gifts and income, debt and equity transactions are common and tied closely to practical human experience. Whether through personal loans, mortgages, or stock ownership, experience with instruments of debt or equity outside the courtroom is common. Therefore, the legal standard is accessible and practical, and points towards the efficacy of a deferential standard.

2. Institutional advantages of the courts favor deference.

Trial and appellate courts differ on many dimensions, including the evidence they review and the decisionmaking process they use. These attributes create institutional advantages for solving certain legal problems. For the purposes of this inquiry, these attributes can be separated into two distinct components-superior positioning and special competence.

a) Superior positioning. Trial and appellate courts are positioned differently relative to the parties, evidence and each other. These positions have implications for courts' abilities to make accurate judgments. The Supreme Court has emphasized that in deciding "whether mixed questions of law and fact are to be treated as questions of law or of fact ... sometimes the decision 'has turned on a determination that ... one judicial actor is better positioned than another to decide the issue in question." ${ }^{146}$

Given the nature of debt/equity cases, the trial court is better positioned to make an accurate determination. The debt/equity determination hinges largely on questioning parties, reviewing financial records or related documents, and otherwise gathering and parsing the facts. ${ }^{1.77}$ The trial court, which is engaged in pretrial activities and the presentation of the evidence, is in a superior position for interpreting

144 See, for example, 26 USC $\S 163(a)$ ("There shall be allowed as a deduction all interest paid or accrued within the taxable year on indebtedness.").

145 A "gift" is defined as "[ $t$ ]he voluntary transfer of property to another without compensation." Black's Law Dictionary at 709 (cited in note 10).

146 Pierce, 487 US at 559-60, quoting Miller v Fenton, 474 US 104, 114 (1985). See also Salve Regina, 499 US at 233 ("[D]eferential review of mixed questions of law and fact is warranted when it appears that the district court is 'better positioned' than the appellate court to decide the issue in question.").

147 See, for example, Indmar, 444 F3d at 774-84 (reviewing witness testimony and the factual record); Estate of Mixon v United States, 464 F2d 394, 398 (5th Cir 1972) ("As in most cases of this type, the facts here are both complicated and significant."). 
these facts and determining how much significance to attach to any particular piece of evidence. ${ }^{148}$ For instance, during trial a party may be questioned as to his intent in making the transaction at issue. The trial court's direct observation of the witness's demeanor and responses is likely to provide superior insight compared to the transcript the appellate court will review. For this reason the Court has noted that determinations as to the credibility of witnesses-including assessments of demeanor - justify significant deference to trial courts. ${ }^{145}$

b) Special competence. In large part as a result of their relative positions, trial and appellate courts bring differing competencies to bear. The Supreme Court has often reiterated the relevance of special competence. In Pierce $v$ Underwood,$^{130}$ the Court observed that the trial court's role gives it special competence in "such matters as whether particular evidence was worthy of being relied upon." Court has also noted the special competence of appellate courts. The Court explained that while trial judges "preside alone over fast-paced trials" and "often must resolve complicated legal questions without benefit of extended reflection or extensive information ... appellate judges are able to devote their primary attention to legal issues." 152 They can consult as a multijudge panel, and their more focused inquiry stimulates superior information and analysis from the parties. ${ }^{153}$

In the debt/equity context, the trial court's special competence outweighs that of the appellate court. First, trial courts are likely to be more familiar with the evidence and analysis involved in debt/equity determinations. As noted above, the debt/equity distinction is a frequently litigated issue. Moreover, the circumstances and inquiries involved are likely to be comparable to those involved in other tax contexts in which trial courts must review taxpayers' financial arrangements. Second, debt/equity questions are frequently brought to the Tax Court. Due to the qualifications of its judges and their frequent analysis of similar issues, this court in particular brings a special competence that the appellate courts cannot match.

Notably, a principal advantage of the appellate courts is not highly relevant to this context. Appellate courts are institutionally structured to make accurate determinations of law. Appellate judges

148 See Pierce, 487 US at 560 ("By reason of settlement conferences and other pretrial activities, the district court may have insights not conveyed by the record.... Moreover, even where the district judge's full knowledge of the factual setting can be acquired by the appellate court, that acquisition will often come at unusual expense.").

149 See Miller, 474 US at 114.

150487 US 552 (1988).

151 Id at 560.

152 Salve Regina, 499 US at 231-32.

153 Id at 232. 
have the advantages of superior party briefs and the opportunity to discuss, debate, and decide issues collectively. ${ }^{154}$ But these advantages bring little value to the debt/equity context. In this context, the focus is on factual determinations, and the nuanced nature of the facts and evidence involved make it unlikely that extensive legal research, inquiry, or debate will provide much clarification.

In sum, the institutional advantages of the trial courts, including better positioning and superior competence, point towards a deferential standard of review.

3. The lack of potential for generalized precedent favors deference.

An oft-cited reason to favor independent review is that appellate courts can add significant value in unifying and clarifying the law. The Court has emphasized the role de novo review can play in unifying precedent and stabilizing the law. ${ }^{155}$ But the value of this review lies in whether the cases involve circumstances that lend themselves to generalization. The Court has cautioned that the "fact-bound nature of [a] decision limits the value of appellate court precedent."

Due to their highly nuanced nature, debt/equity determinations resist generalization and provide infertile ground for clarifying and unifying precedent. An example from the case law illustrates this point. In In re Lane, ${ }^{157}$ the Eleventh Circuit affirmed the district court's decision that the plaintiff's advances constituted equity under de novo review. The court's decision was driven by, among other things, (1) the use of the term "notes" to refer to the certificates, (2) the lack of maturity dates on the majority of thirteen notes, (3) the receipt of a 1974 van and $\$ 2,700$ in cash for over $\$ 100,000$ in advances, (4) the lack of initiative to guaranty repayment, (5) the failure to establish a sinking fund, and (6) the plaintiff's specific description of his relationship to the corporations. ${ }^{158}$ These facts are specific to the case, and their undisclosed importance in the ultimate decision illustrates the limited value of the

154 See Salve Regina, 499 US at 232 ("[I]t can be expected that the parties' briefs will be refined to bring to bear on the legal issues more information and more comprehensive analysis than was provided for the district judge. Perhaps most important, courts of appeals employ multijudge panels ... that permit reflective dialogue and collective judgment.").

155 See, for example, Ornelas v United States, 517 US 690, 696 (1996).

156 Buford v United States, 532 US 59, 64 (2001). See also Ornelas, 517 US at 703 (Scalia dissenting) ("[1]n Pierce v. Underwood ... a principal basis for our applying an abuse-of-discretion standard ... was that the question was 'a multifarious and novel question, little susceptible, for the time being at least, of useful generalization."') (citations omitted).

157742 F2d 1311 (11th Cir 1984).

158 Id at 1315-18. 
precedent that resulted. The absence or significant alternation of any of these factors in future cases would render this precedent inapposite. ${ }^{159}$

As demonstrated by the case law, the decisions in debt/equity cases are inherently tied to factual arrangements that are unlikely to be repeated. Consequently, the typically strong pillar of appellate scrutiny collapses under the highly nuanced and fact-intensive context of debt/equity determinations.

4. The self-containment of the legal standards favors deference.

The Court has reasoned that when a legal standard depends on application for meaning, greater scrutiny is warranted. For instance, in Ornelas $v$ United States, ${ }^{100}$ a Fourth Amendment case, the Court reasoned that deference was inappropriate because probable cause and reasonable suspicion rules "acquire content only through application." ${ }^{161}$ If a legal standard is vacuous in the abstract, deference is disfavored to guard against unpredictable and ill-defined legal standards.

The question is whether the terms "debt" and "equity" are similarly dependent on application, and the answer is they are not. Though "debt" and "equity" take on nuanced meanings in specific contexts, their inherent character is commonly understood and relatively clear. Unlike "reasonable suspicion," which is defined by application, debt and equity are identified through application but can be defined in the abstract. Debt signals an obligation to repay something owed. Equity signals a stake in an enterprise. These standards are self-sufficient. Given the convoluted arrangements that arise in practice, it may even be argued that standards of debt and equity retain their meanings despite application rather than because of it. Thus, the clarity of the abstract standards and absence of a dependency on application for substance points again towards a deferential standard.

5. The limited dangers of discretion and advantages of flexibility favor deference.

One of the risks of deferential appellate review is that legal enforcement is likely to be more varied. By contrast, independent appellate review allows courts of appeals not only to clarify and unify law, but also to ensure that results of individual cases strictly follow precedent. The Court deemed this variance "unacceptable" in the Fourth Amendment context. ${ }^{162}$ Specifically, the Court noted that without ap-

\footnotetext{
159 For a similar analysis, see Ornelas, 517 US at 703-04 (Scalia dissenting).

160517 US 690 (1996).

161 Id at 697 .

162 Id.
} 
pellate scrutiny, Fourth Amendment protections would be subject to the individual determinations of trial judges. ${ }^{163}$ However, this concern may not translate to the debt/equity context. In the debt/equity context, the stakes are different. Rather than constitutional protections, debt/equity cases involve tax deficiencies. So it is unclear whether the same concerns about varied results that arise in the context of Fourth Amendment law are applicable in the debt/equity context.

Moreover, discretion may have its advantages. The Court has asserted that where the number of factual permutations is significant, greater deference gives needed flexibility to address this variance. ${ }^{164}$ The debt/equity context is likely to benefit from this flexibility. The factual circumstances of each case vary widely, especially since courts consider many discrete aspects of the transaction. The number of permutations is likely to be high, and trial courts will benefit from exercising their discretion without the restrictive weight of de novo appellate review.

In sum, the danger discretion poses is less of a concern in this context, and the advantages of flexibility point towards a deferential stance.

6. The significant stakes involved favor independent review.

Finally, the gravity of the stakes may bear on the appropriate level of appellate review. The Court has asserted that substantial liabilities militate against deferential standards of review. ${ }^{165}$ For instance, in Pierce $v$ Underwood, the Court noted that substantial sums of liability -in that case the appellate court reviewed an award of over $\$ 1,000,000-$ argue in favor of independent review. ${ }^{166}$ This makes sense, as high stakes increase potential error costs and make an investment in appellate scrutiny worthwhile.

The Supreme Court stated that with regard to stakes, "the generality rather than the exception must form the basis for our rule."167 Debt/equity cases, especially those appealed, often involve sizeable sums. Individual taxpayers, for instance, have often appealed deficiency assessments of several hundred thousand dollars. ${ }^{168}$ Corporate taxpayers may seek refunds of even higher amounts, often in the mil-

163 Id.

164 Pierce, 487 US at 562 (noting that where "the number of possible situations is large, we are reluctant either to fix or sanction narrow guidelines for the district courts to follow").

165 Id at 563 .

166 Id

167 Id.

168 See, for example, Crowley v Commissioner, 962 F2d 1077, 1078 (1st Cir 1992) (\$206,935 at stake); Jaques v Commissioner, 935 F2d 104, 105 (6th Cir 1991) (\$446,609 at stake); Mixon, 464 F2d at $398(\$ 126,964$ at stake $)$. 
lions. ${ }^{169}$ Thus, in general debt/equity cases involve significant sums of money. This fact points in favor of de novo review as long as appellate review is likely to minimize error.

\section{Additional Considerations Unique to This Context}

In addition to the six considerations distilled from precedent, the unique circumstances of debt/equity cases provide three additional factors relevant to the optimal level of deference. These factors arise from the government's potential and actual advantages at trial, the ability of taxpayers to choose from several forums in which to bring their cases, and parties' responses to uncertainty. Like most of the factors considered above, these also point towards the efficacy of a deferential standard.

1. Leveling the playing field.

An argument in favor of de novo review is that it is needed to level the playing field between the parties. At trial, the IRS may have two key advantages. First, the IRS is a repeat litigant in the trial courts, especially the Tax Court. Such repetition may lead to a bias in favor of the government, as trial judges become familiar with government attorneys and practices. If this is accurate, courts of appeals may provide an important check on pro-IRS bias at the trial level. Second, in debt/equity cases, the IRS Commissioner's determination is held to be presumptively correct. Given this IRS advantage, a more searching standard of review may be necessary to ensure accuracy and avoid a rubber stamp.

Although these concerns may be more thoroughly addressed by greater appellate scrutiny, it is not clear that either is valid. First, a deferential standard of review would still enable the appellate court to correct judgments that are plainly incorrect. Second, placing the burden on the defendant taxpayer makes sense. The taxpayer has superior information about the relevant facts, which are central to the debt/equity determination. It could be argued that the pro-IRS presumption levels, rather than distorts, the playing field, as it places the onus on the party with the lowest cost of obtaining information. Thus, while appellate deference may resolve these concerns, it is not clear that these concerns should be given much weight in the first place.

169 See, for example, Roth Steel Tube Co v Commissioner, 800 F2d 625, 626 (6th Cir 1986) (over $\$ 1.7$ million at stake); Dolese v United States, 605 F2d 1146, 1148 (10th Cir 1979) (over $\$ 1.5$ million at stake). 
2. Reduce forum shopping.

Taxpayers who want to file a claim disputing a debt/equity characterization can file their claims in a district court, Tax Court, Federal Claims Court, or sometimes a bankruptcy court. While the Tax Court provides the distinct advantage that the taxpayer does not need to pay the deficiency before filing his complaint, taxpayers may select the court that they believe will give them the most advantageous treatment.

If such forum shopping is undesirable, a deferential standard of review is the better choice. As discussed above, appellate deference to the Tax Court has long been an issue, and many have argued that such deference is proper given the court's special expertise. Intuitively, it is easy to imagine an appellate judge giving less scrutiny to a ruling from a judge specially trained in tax matters than to a judge of general jurisdiction. Parties, and their lawyers, may suspect this as well.

As an empirical matter, it is difficult to determine whether debt/equity decisions arising from the Tax Court receive different appellate treatment than those arising from district courts. ${ }^{170}$ But to the extent that skepticism exists, a uniform deferential standard would reduce forum shopping in the debt/equity context. It would set the expectation that all trial courts receive significant deference, and thereby undermine the perception that the Tax Court receives significant deference while district courts do not.

\section{Encourage greater transactional clarity.}

There is still an advantage to deferential review even if, contrary to the analysis provided above, appellate review would decrease error. In the debt/equity context, cases often arise due to imprecision in structuring financial transactions." ${ }^{\text {1" }}$ Actors may not clearly document their transactions either accidentally or in hopes of leaving room to maneuver once the transaction has played itself out. ${ }^{172}$

Some marginal inaccuracy may have value in this context. If parties are aware that their tax deficiency cases will not be scrutinized by an appellate court, they may perceive a greater cost of imprecision. Rather than having two forums, parties will have only one shot at fully presenting their cases. Some parties may leave less to chance as a re-

170 A survey of fifty-five debt/equity appellate cases revealed that twenty-eight of thirty-six Tax Court decisions were affirmed, while fifteen of nineteen district court decisions were affirmed. See Appendix, Table 2: Rate of Reversal by Type of Lower Court.

171 See, for example, Indmar, 444 F3d at 774-84 (reviewing the convoluted financial transactions at issue).

172 Id at 780 (noting that the desire to minimize taxes acts "as a flag to the Commissioner and courts to look closely at the transaction for any objective indicia of debt"). 
sult. Consequently, even if greater deference does result in more error, this may encourage greater transactional clarity and thus may be preferable to investing in reducing this error further.

\section{Level of Deference}

The preceding review of six considerations drawn from Supreme Court precedent and three strategic considerations unique to the debt/equity context suggests that debt/equity determinations should receive significant deference. The efficacy of deference is supported by the nontechnical nature of the legal standard, the special competence and superior positioning of the trial court, the self-containment of the legal standard, and the benefits of providing trial courts with flexibility for nuanced cases. While appellate courts play an important role in unifying precedent, the potential to do so in the debt/equity context is limited. Furthermore, a deferential standard may reduce forum shopping and encourage parties to be clearer when structuring their transactions. There are two considerations that support less deference-the significant stakes involved in debt/equity cases, and possible pro-IRS bias at the trial court level. However, since the stakes involved do not rise to the level of constitutional rights, and the concern about a proIRS bias is highly speculative and contentious, these two factors do not outweigh the weight of the analysis pointing in the opposite direction.

Since nearly all the criteria considered suggest that a deferential standard of review is appropriate for debt/equity determinations, de novo review cannot be the optimal choice. For similar reasons, neither can the Tenth Circuit's contingent review approach. ${ }^{173}$ But deciding that a deferential standard of review is optimal leaves two possibilities-abuse of discretion or clearly erroneous. Though both offer the benefits of increased deference, they have different legal and practical implications.

The clearly erroneous standard bears at least one distinct practical advantage. It plainly articulates that all aspects of the debt/equity determination are factual and are best handled by the trial court. This standard of review, therefore, offers the clearest resolution. In addition, if parties are sensitive to the standard of review, then a clearly erroneous standard may most efficiently encourage them to consider and identify their transactions ahead of time for the reasons discussed above. After all, they will know that nothing in court will be considered other than the factual trail of their transactions.

173 This approach was suspect to begin with, as the Tenth Circuit seemed to have great difficulty applying its own standard. See, for example, Williams v Commissioner, 627 F2d 1032, 1035 (10th Cir 1980) (issuing a decision despite confusion over "[w]hether the record presents a fact question, a law question, or a mixed question of law and fact"). 
However, abuse of discretion is a better standard for three reasons. First, the abuse of discretion standard captures the different character of the two separate phases of inquiry. In one phase, the trial court makes factual determinations of discrete criteria, such as the maturity date or the name given to the instrument. In the other phase, the court must decide which indicia are relevant, how relevant they are, and what legal treatment the record as a whole warrants. As the Court clarified in Townsend $v$ Sain: ${ }^{174}$

By "issues of fact" we mean to refer to what are termed basic, primary, or historical facts: facts "in the sense of a recital of external events and the credibility of their narrators ...." So-called mixed questions of fact and law, which require the application of a legal standard to the historical-fact determinations, are not facts in this sense. ${ }^{175}$

Describing both stages as factual determinations ignores the balancing and discretion involved in the second stage. ${ }^{176}$

The abuse of discretion standard recognizes that the second stage involves two exercises of legal discretion. The trial judge must first use his discretion to decide which indicia are relevant, and second he must assign weights to these indicia and derive an answer. In the end, rather than rely on legal precedent or statutory text, or solely the facts of the case, the trial judge makes discretionary judgments to balance the indicia. ${ }^{17}$ In addition to having analytical appeal, separating the two stages of inquiry may have pragmatic benefits. Trial judges may respond to this clear framework by more rigorously distinguishing their factual findings and substantiating their discretionary decisions.

This leads to the second advantage of abuse of discretion review. "Under the clearly erroneous standard, [a court] cannot reweigh the

174372 US 293 (1963).

175 Id at 310 n 6 (overruled on other grounds), quoting Brown v Allen, 344 US 443, 506 (1953). See also Ornelas, 517 US at 701 (Scalia dissenting) (noting that when the inquiry "requires application of an objective legal standard to the facts, it is properly characterized as a mixed question of law and fact").

176 In John Kelley Co v Commissioner, 326 US 521 (1946), the Court observed, "it might be said to be a question of law as to whether the primary facts adduced made the payments under consideration dividends or interest." Id at 529. But the Court continued, "such conclusion gives inadequate weight to the purpose of the Tax Court." Id. However, this case arose after Dobson gave the Tax Court final say on all issues not clearly a question of law. Once Congress passed 26 USC $\$ 7482$, requiring appellate courts to review Tax Court decisions in the same manner as other courts, this rebuttal was no longer valid and the underlying observation seems more relevant.

177 See Baumgartner v United States, 322 US 665, 671 (1944) ("Finding so-called ultimate 'facts' more clearly implies the application of standards of law.").

178 For instance, guided by the notion that he is doing something other than establishing facts, a trial judge may be encouraged to articulate the relative weight he attaches to each factor, as well as his reasons for excluding factnr- 
evidence." ${ }^{179}$ But an abuse of discretion standard both acknowledges the discretion exercised by the trial court and attaches more rigorous appellate review at the point where the inherent advantages of the trial court are at their weakest and where the appellate court can add the greatest value-deriving the proper pool of criteria and balancing them accurately. ${ }^{180}$ An abuse of discretion standard thus recognizes that the debt/equity determination is a mixed question of fact and law, and focuses the appellate review where it can be most beneficial.

Third, the abuse of discretion standard best harmonizes the circuits' existing positions. For factual determinations, there is no difference between a clearly erroneous and abuse of discretion standard. ${ }^{181}$ This aligns the abuse of discretion standard with the majority stance for a significant portion of the issue. However, the abuse of discretion standard also finds common ground with the approaches of the Fifth, Tenth, and Eleventh Circuits. Each of these courts hold that determination of the historical facts is a separate inquiry from making a legal judgment based on the weight of the facts. The abuse of discretion standard recognizes this distinction. The significant change it makes is in requiring a greater degree of deference in these determinations. However, as discussed earlier, there are strong justifications for doing so.

\section{E. Beyond Existing Precedent}

Though the D.C. Circuit previously concluded in Cerand that abuse of discretion is the proper standard of review, the foregoing analysis provides an original and robust pathway to this conclusion. This D.C. Circuit's discussion centered on a brief recitation of two of the arguments used in Cooter \& Gell-that abuse of discretion is warranted where there is limited potential for precedent and the trial court is better positioned. ${ }^{182}$ Rather than relying on a single overlapping case, this Comment presents an alternative approach based on distilling criteria from a series of cases and considering practical implications as well.

Since ten circuits have implemented a standard other than abuse of discretion, a robust analysis is needed to justify this significant change. In particular, the seven circuits applying a clearly erroneous standard are unlikely to be persuaded by the D.C. Circuit's brief analysis. After all, clearly erroneous review takes account of the trial

179 Busch, 728 F2d at 951.

180 See, for example, Indmar, 444 F3d at 781 (asserting that criteria such as the lack of maturity date and the fixed obligation to repay should carry little weight).

181 See Cooter \& Gell, 496 US at 401.

182 See Cerand, 254 F3d at 261. 
court's positioning and the limited potential for broad precedent. In comparing a clearly erroneous standard with an abuse of discretion standard, this Comment clarifies why the latter has a distinct advantage beyond the arguments the D.C. Circuit made in Cerand.

\section{CONCLUSION}

Despite the frequency with which debt/equity cases arise, the circuits have been split over the proper standard of review for these determinations. Though most circuits review for clear error, other circuits utilize a de novo standard, a contingent review standard incorporating clear error and de novo, and an abuse of discretion standard. Doctrinal and pragmatic considerations indicate that debt/equity determinations should be reviewed dcferentially. Between deferential standards, abuse of discretion is the appropriate choice. This standard is sensitive to the fact-intensive nature of debt/equity inquiries, but also to the separate stages of analysis and the discretion involved therein. Although it is currently supported by a single court of appeals and has been applied in a single case, the abuse of discretion standard balances and harmonizes the other courts' approaches. Dispute over this issue has split the courts of appeals for several decades. Adopting an abuse of discretion standard will provide an effective bridge to close this old divide. 


\section{APPENDIX}

The following table reflects debt/equity cases in which the appellate court clearly stated the standard of review it was applying.

TABLE 1

RATE OF REVERSAL BY STANDARD OF REVIEW

\begin{tabular}{lccr}
\hline & Affirmed & Reversed & \% Reversed \\
Clearly erroneous & $26^{183}$ & $4^{184}$ & $13 \%$ \\
De novo & $5^{185}$ & $4^{186}$ & $44 \%$ \\
Total $^{187}$ & 31 & 8 & $23 \%$
\end{tabular}

183 See generally In re SubMicron Systems Corp, 432 F3d 448 (3d Cir 2006); Ginsberg v Commissioner, 1993 US App LEXIS 21519 (6th Cir); Crowley v Commissioner, 962 F2d 1077 (1st Cir 1992); Jaques v Commissioner, 935 F2d 104 (6th Cir 1991); Roth Steel Tube Co v Commissioner, 800 F2d 625 (6th Cir 1986); Piggy Bank Stations, Inc v Commissioner, 755 F2d 450 (5th Cir 1985); Busch v Commissioner, 728 F2d 945 (7th Cir 1984); Wilkof v Commissioner, 636 F2d 1139 (6th Cir 1981); Plantation Patterns, Inc v Commissioner, 462 F2d 712 (5th Cir 1972); Livernois Trust v Commissioner, 433 F2d 879 (6th Cir 1970); A. R. Lantz Co, Inc v United States, 424 F2d 1330 (9th Cir 1970); Tollefsen v Commissioner, 431 F2d 511 (2d Cir 1970); Road Materials Inc v Commissioner, 407 F2d 1121 (4th Cir 1969); Berthold v Commissioner, 404 F2d 119 (6th Cir 1968); Smith v Commissioner, 370 F2d 178 (6th Cir 1966); Fellinger v United States, 363 F2d 826 (6th Cir 1966); Foresun, Inc v Commissioner, 348 F2d 1006 (6th Cir 1965); McSorley's, Inc v United States, 323 F2d 900 (10th Cir 1963); Estate of Chism v Commissioner, 322 F2d 956 (9th Cir 1963); Taft v Commissioner, 314 F2d 620 (9th Cir 1963); Charter Wire, Inc v United States, 309 F2d 878 (7th Cir 1962); O. H. Kruse Grain \& Milling v Commissioner, 279 F2d 123 (9th Cir 1960); Wilbur Security Co v Commissioner, 279 F2d 657 (9th Cir 1960); Earle v W. J. Jones \& Son, Inc, 200 F2d 846 (9th Cir 1952); Talbot Mills v Commissioner, 146 F2d 809 (1st Cir 1944); United States v Title Guarantee \& Trust Co, 133 F2d 990 (6th Cir 1943).

184 See generally Indmar Products Co, Inc v Commissioner, 444 F3d 771 (6th Cir 2006); Mills v IRS, 840 F2d 229 (4th Cir 1988); Bauer v Commissioner, 748 F2d 1365 (9th Cir 1984); Taft $\checkmark$ Commissioner, 314 F2d 620 (9th Cir 1963).

185 See generally In re Lane, 742 F2d 1311 (11th Cir 1984); Slappey Drive Industrial Park $v$ United States, 561 F2d 572 (5th Cir 1977); Estate of Mixon v United States, 464 F2d 394 (5th Cir 1972); Berkowitz v United States, 411 F2d 818 (5th Cir 1969); Harlan v United States, 409 F2d 904 (5th Cir 1969).

186 See generally Texas Farm Bureau v United States, 725 F2d 307 (5th Cir 1984); Joseph Lupowitz Sons, Inc v Commissioner, 497 F2d 862 (3d Cir 1974); United States v Snyder Brothers Co, 367 F2d 980 (5th Cir 1966); Commissioner v John Kelley Co, 146 F2d 466 (7th Cir 1944).

187 Busch, 728 F2d at 951. 
The following table reflects debt/equity cases arising after 1948 , the year that Congress mandated that appellate courts review Tax Court decisions in the same manner as district court decisions. ${ }^{188}$

TABLE 2

RATE OF REVERSAL BY TYPE OF LOWER COURT

\begin{tabular}{lrrr}
\hline & Affirmed & Reversed & \% Reversed \\
Tax court & $28^{189}$ & $8^{190}$ & $22 \%$ \\
District court & $15^{191}$ & $4^{192}$ & $21 \%$ \\
Total & 43 & 12 & $22 \%$
\end{tabular}

188 In many of these cases, the court did not articulate a standard of review. Consequently, no differentiation has been made for the standard of review under which each decision has been affirmed or reversed.

189 See generally Jensen $v$ Commissioner, 2000 US App LEXIS 4664 (10th Cir 2000); Plante $v$ Commissioner, 168 F3d 1279 (11th Cir 1999); Ginsberg, 1993 US App LEXIS 21519; Crowley, 962 F2d 1077; Jaques, 935 F2d 104; Roth Steel, 800 F2d 625; Piggy Bank Stations, 755 F2d 450; Busch, 728 F2d 945; Stinnett's Pontiac v Commissioner, 730 F2d 634 (11th Cir 1984); Wilkof, 636 F2d 1139; Williams, 627 F2d 1032; Trans-Atlantic Co v Commissioner, 469 F2d 1189 (3d Cir 1972); Plantation Patterns, 462 F2d 712; Livernois Trust, 433 F2d 879; Tollefsen, 431 F2d 511 (cited in note 190); Road Materials, 407 F2d 1121; Berthold, 404 F2d 119; Smith, 370 F2d 178; Fellinger, 363 F2d 826; Foresun, 348 F2d 1006; Estate of Chism, 322 F2d 956; Taft, 314 F2d 620; Montclair v Commissioner, 318 F2d 38 (5th Cir 1963); PM Finance Corp v Commissioner, 302 F2d 786 (3d Cir 1962); O. H. Kruse, 279 F2d 123; Wilbur Security, 279 F2d 657; Gregg Co v Commissioner, 239 F2d 498 (2d Cir 1956); Gooding Amusement Co v Commissioner, 236 F2d 159 (6th Cir 1956).

190 See generally Indmar, 444 F3d 771; Mills, 840 F2d 229; Bauer, 748 F2d 1365; Joseph Lupowitz, 497 F2d 862; Taft, 314 F2d 620; Kraft Foods Co v Commissioner, 232 F2d 118 (2d Cir 1956); Wilshire \& Western v Commissioner, 175 F2d 718 (9th Cir 1949); Bowerstock Mills \& Power v Commissioner, 172 F2d 904 (10th Cir 1949).

191 See generally In re SubMicron Systems Corp, 432 F3d 448; In re Lane, 742 F2d 1311; Dolese, 605 F2d 1146; Slappey Drive, 561 F2d 572; Mixon, 464 F2d 394; Estate of Taschler v United States, 440 F2d 72 (3d Cir 1971); A.R. Lantz Co, 424 F2d 1330; Berkowitz, 411 F2d 818; Harlan, 409 F2d 904; Fin Hay Realty Co v United States, 398 F2d 694 (3d Cir 1968); Tomlinson v 1661 Corp, 377 F2d 291 (5th Cir 1967); Fellinger, 363 F2d 826; Charter Wire v United States, 309 F2d 878 (7th Cir 1962); Earle, 200 F2d 846; Maloney v Spencer, 172 F2d 638 (9th Cir 1949).

192 See generally Texas Farm, 725 F2d 307; In re Uneco, 532 F2d 1204 (8th Cir 1976); United States $v$ Henderson, 375 F2d 36 (5th Cir 1967); Snyder Brothers, 367 F2d 980. 


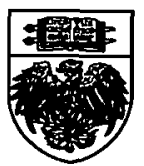

